\title{
Jordanian Social Studies Teachers' Perceptions of Competency Needed for Implementing Technology in the Classroom
}

\author{
Mohammad Al Bataineh \\ Jordan University of Science and Technology, Jordan \\ Sharon Anderson \\ Colorado State University, United States
}

\begin{abstract}
This study used a cross-sectional, ten-point Likert-type scale survey design, to examine the perception of Jordanian seventh to twelfth-grade social studies teachers of the competency needed for technology implementation in their classrooms. The instrument for this study was a modified version of a survey developed by Kelly (2003) called the Technology in Education Survey (TIES). The scale ranged from 1-10, with 1 being the lowest score, indicating not important or not competent, and 10 being the highest score, indicating very important or very competent. Due to the cultural context of the study, the researcher used an Arabic-language version of the survey used by Al Ghazo (2008). The convenience sample $(n=221)$ was a blend of male $(n=135)$ and female teachers $(n=86)$. A significant interaction was found between age and gender of social studies teachers and their perceptions of competency needed to implement technology. Female teachers who were thirty or younger and who were thirty-one to thirty-nine scored the highest mean of perceptions of competency toward implementing technology in social studies classrooms, higher than all male teachers, while male and female teachers who were forty or older scored the same lowest mean (49.5) of perceptions of competency. Female teachers with the least teaching experience had high perceptions of competency for implementing technology in social studies classrooms, while female teachers with the most teaching experience had lower perceptions of competency than male teachers. The result of the study provides useful information to social studies educators, professional development leaders, national policy makers and teachers of social studies who are interested in understanding the factors that affect technology use in social studies classrooms in Jordan.
\end{abstract}

Keywords: Social studies education; Educaional technology implementation; Teacher competency; Technology in the classroom

\section{Introduction}

Located in the Middle East, Jordan is an Arab country with a Muslim majority and a Christian minority. It is situated South of Syria, South West of Iraq and Saudi Arabia and East of Israel and Palestine. Both the rich ancient and modern history of Jordan shapes its geopolitical; its relations with neighboring states as well as governance at the local level. Regional conflict as well as local 
political tensions constantly altered its socio-political trajectory during the course of the last fifty years. In parallel, the school system went through continuous and rapid change. (Alazzi, 2008).

Alazzi (2008) outlined different time frames that have shaped social studies curriculum in Jordan. These key historical and political events can be divided into four main time frames: (a) 1921-1951; (b) 1952-1977; (c) 1978-1989; (d) 1990 to the present.

The 1921-1951 phase marked the Israeli Arab Conflict of 1948, a tension that had its socioeconomic and political impact from one side and the paved way for progress in social studies in Jordan. Politically, the British mandate put the Jordanian sovereignty under Britain rule. Both social studies and the educational curriculum were controlled by the colonizer. With that, the curriculum advanced British colonial interests and policy. The fields of history and geography were of main interest (Alazzi, 2008).

Between 1952 and 1977 further social studies development took place. By then Jordan gained its independence. The Ministry of Education started overshadowing development and restructure of various educational fields and social studies. The ministry added six new subjects to social studies. These were Arabic history, Arabic geography, the Arab world, philosophy, sociology, childhood education, and women's education. The main teaching methods of this era relied heavily on lecturing and rote memorization. As it could be deduced from the new subjects, social studies curriculum focused Arabic language and Arabic identity. Countries with special diplomatic relations with Jordan were given more attention (Alazzi, 2008).

During the third milestone in social studies development, from 1978 to 1989, the Ministry of Education relied on expert knowledge and empirical research for the textbook write up and integration in the curriculum. Ministry of Education reduced the number of social studies subjects from eight to only three, namely history, geography, and Arabic society. As opposed to the second phase, more focus was on quality than quantity during this period. History subject incorporated larger units, such as Arabic, the history of Islam and modern world history to count a few. The Palestinian problem and Israeli-Arab conflict were a major area of struggle, which in turn, had their weight on the nation's political economy. Geography subject covered the Arab world, Europe, North and America (Alazzi, 2008).

The Gulf War of 1990 had its impact on social studies curriculum development in Jordan. This war brought about an unprecedented disaster and a disruption of regional exchange; Jordan's diplomatic relations with some neighboring states were jeopardized since the country took a neutral position on the war.

At the same time, three key political strategies have contributed to an improvement in Jordan's economy. Jordan had invested in peace pacts with neighboring states; initially Jordan brokered peace between Palestine and Israel then between the Jordan itself and Israel. This bold move came with substantial economic back up from the United States to Jordan as one of the mediators in peace making. The third move involved a World Bank's excuse to Jordan from debts and a deferment to the remaining debts (Alazzi, 2008). 
This also came with positive and negative consequences on social studies curriculum. The draw back of such change was manifested in the social studies curriculum inability to effectively handle escalation of events; especially when it came to stressing critical thinking and reflexivity. However, geopolitical events contributed to the emergence of a new social studies curriculum, amongst which civic egagement and citizenship (Alazzi, 2008).

In a study that targeted English language learners, Abu Samak (2006) examined the factors that may impact Jordanian English Foreign Language (EFL) teachers' attitudes toward information and communication technology. The findings showed that Jordanian EFL teachers held positive attitudes toward information and communication technology. Also, Jordanian EFL teachers had high access to technology and moderate competency. Other factors such as age and teaching experience showed an inverse relationship between these factors and teachers' attitudes.

The integration of technology has also been studied in several Middle Eastern countries. Al Mekhlafi and Al Meqdadi (2010) studied technology integration in K-12 schools in the United Arab Emirates. The authors used a mixed method that included focus groups, interviews, and a questionnaire with a sample of 100 teachers. The findings showed that schools in the UAE were progressive at integrating technology in their classes. The teachers also used a variety of technology tools such as computers with different software, transparencies, the Internet, maps, flyers, and folded papers. Second, there were differences between male and female teachers in regard to the methods of integrating technology; female teachers used different technology tools more than the male teachers. Third, female teachers had more experience, usage, and familiarity of technology tools and applications than male teachers. Fourth, both male and female teachers at UAE Model Schools had high self-perception of their skills and competency to implement technology effectively in their classrooms. Finally, results indicated that both genders highly regarded their competencies in technology implementation.

In Egypt, Bakr (2011) examined the attitudes of Egyptian teachers toward computers. The study sample consisted of 118 public school teachers; 53 males and 65 females. The findings showed that Egyptian public school teachers' attitudes toward computers and computer use were positive. Also, the results showed no significant differences in terms of gender and teaching experience regarding the use of technology.

Erdoğan (2011) investigated Turkish primary school teachers' perceptions of school culture of ICT integration in education with a sample of 1,540 primary school teachers. Results showed that the teachers' perceptions of school environments regarding the motivational and technical features were not supportive and negative. Also, results showed that the perceptions of teachers who did not own a personal computer and had little access to the Internet were found to be much more negative toward school ICT culture than those who owned a personal computer and had access to the Internet.

Additionally, Akengin (2008), conducted a qualitative study that examined the uses of information technologies in the field of social studies in Turkey. His research consisted of interviews of twenty prospective teachers studying in a social studies teaching program in Turkey. The results showed that "prospective teachers were acquainted with computers, the internet and projectors the most from among the information technologies and think that these technologies were utilized at schools 
and teacher training programs" (Akengin, 2008, p. 126). Akengin concluded that technology was commonly used as a teaching tool to help enhance student comprehension in Turkey. Different technologies are useful in different situations. For example, using the Internet to show images of geographical phenomenon would be helpful for students. Using a projector to display these images would be even more helpful for student comprehension.

During the research process, the interviewees were asked a series of questions about information technologies, the definition of information technology, and the use of information technologies in the classroom. Some interviewees were unable to provide a definition and use for information technology. The most common answers for information technologies used were computers, overhead projectors and the Internet. One prospective teacher in the study said, "The Internet is an incredible bookcase, a library for me" (Akengin, 2008, p. 131). Additionally, the prospective teachers expressed that the disadvantages for using technology were that it may "results in research laziness, decrease in student participation, and it increases teacher prep time for a lesson" (p. 136).

In summary, the literature on technology implementation in Jordan and the Middle East points out several trends. First, teachers generally have positive attitudes toward using and implementing technology (Alazzi, 2008; Al Zaidiyeen et al., 2010). Second, schools in poor countries such as Jordan and Egypt lack an appropriate level of technology (e.g., not enough computers). Meanwhile, in rich countries such as the United Arab Emirates, schools are better equipped with technology, and the implementation of technology is very advanced (Al Mekhlafi and Al Meqdadi, 2010). Third, teachers' attitudes and beliefs about technology are affected by a variety of variables, such as the availability of technology, self-efficacy, technology proficiency, and perceived usefulness of technology (Hew \& Brush, 2007).

\section{Technology Integration in the Classroom}

Gorder (2009), studied K-12 teachers who had attended a professional development program in South Dakota to examine how well those teachers integrated technology into their classrooms. The study focused on three areas: the barriers teachers face in technology integration, the professional development teachers need in order to continue to use educational technology, and the impact of professional development on the integration of technology into the classroom. A survey was given to $300 \mathrm{~K}-12$ teachers. Overall, the study was able to identify that the teachers who participated were knowledgeable when it comes to working with technology. The participants felt the biggest barrier to being able to integrate technology into their classroom was time to prepare lessons. They felt they needed a large time commitment to accomplish this goal. The support the participants received was largely tied to existing technology. They felt they received the least support when it came to new technology.

Lu and Overbaugh (2009), conducted a study on teachers' perceptions concerning the barriers that prevent them from integrating technology within their classroom. The researchers believed that environment has a significant impact on teacher-technology integration. They looked at rural and urban schools, and elementary and high schools. Overall, the study showed that Virginia had a good technology-implantation program. The schools provided voluntary professional development to those who wished to increase their technology skills and usage. Teachers had a variety of technology 
to choose from; however, teachers in rural areas were limited more than urban schools. No significant difference for technology usage between elementary and high schools was found. Rural schools had a more difficult time getting up-to-date equipment and support.

Vannatta and Fordham (2004), investigated 170 teachers' attitudes as predictors of technology use among K-12 teachers. Results revealed that the combination of factors, including amount of technology training, time spent in the workweek, and openness to change were predictors of classroom technology use.

Ching, Hung, and Lee (2008), examined the relationship between teachers' beliefs about their instruction and uses of technology with a sample of 582 pre-service teachers. The correlation analysis revealed that constructivist teaching was significantly correlated with constructivist use and traditional use, while traditional teaching was correlated negatively with constructivist use. Moreover, a weak and negative association was shown between traditional teaching and traditional use. The results showed that constructivist teaching and traditional teaching were negatively correlated. Multiple regressions showed that constructivist use and age significantly predicted traditional use, and constructivist teaching and age significantly predicted constructivist use.

Goedde (2006) examined the best factors (ATC score, socioeconomic status, district in-service teacher variables: number of years' experience and hours of technology related professional development) that predicted pre-service teacher technology competency. The sample was 278 teachers in school districts located in Ohio during Fall 2004- Spring 2005. The data were generated from two resources: the Assessment of Technology Competency (ATC) retake survey, which is administered for pre-service teachers, and two additional existing sources of data for gathering information about pre-service teacher background experiences.

Findings revealed no significant correlation between pre-service teacher technology competency and average teacher years of experience and district household median income. Also, a very slight positive relationship was found between average number of teacher hours of professional development and median household income. However, the researcher could not conclude the relationships that affect pre-service teacher technology competency. As a result, a significant regression model was not generated.

Woods, Karp, Miao, \& Perlman (2008) examined K-12 physical educators' technology competencies and usage. The sample was 114 physical educators who assessed their perceived competency, usage of technology, the issues of technology, and where they learned to use technology. The sample was members in the Northwest District Association of the American Association of Health, Physical Education, Recreation and Dance (NWD). Results showed a significant difference for gender when physical education teachers assess their own competency of general technology. As a result, male teachers perceived themselves to have higher levels of competence than female teachers. While, no significant difference was found in terms of school level and teaching experience. Furthermore, results indicated a significant difference between school levels when teachers assess their competency of technology use specific to physical education. While no significant differences were demonstrated for gender, or years of teaching.

In summary, research on technology implementation shows that several variables, such as: the amount of technology training, time spent on technology, openness to change, time used for 
preparation, and support and availability of up-to-date technology equipment can affect implementation. The perception of technology effectiveness and benefits seems to play a major role in technology implementation.

The literature reviewed pointed out that teachers' perceptions are varied; some support technology use, while others are worried about the effects of its use. Finally, previous research has pointed out the need for teachers to improve their skills in integrating technology, since teachers' knowledge and skills using technology impacts their attitudes. Teachers' experience in using technology makes them more comfortable to utilize technology (Spaulding, 2007).

Furthermore, while research on educational technology implementation within K-12 is pervasive, research on technology education implementation in content areas such as social studies is limited. In contrast, educational technology research in the United States has been moving toward examining the impact of technology implementation in specific content areas.

As the role of technology in education is rapidly increasing worldwide, developing countries' have begun responding with technology utilization and implementation (Abuhmaid, 2008). For example, the Jordanian government's commitment to excellence in education has been a driving force in spite of the challenges in infrastructure, resources, and planning (El-Hmaisat, 1998; Rumzan, Chowdhury, Mirza, \& Idil, 2010). In addition to Jordanian governmental efforts to equip schools with technology (i.e., computers and Internet connections), there is also gradual growth in the use of technology in Jordanian homes (Khaswneh \& Al-Awidi, 2008).

Other research has pointed out that developing countries face challenges in implementing educational technology. The lack of technological infrastructure (i.e., computers, Internet connectivity) and the lack of faith in the importance of such technology, are some of these challenges (Dirani \& Yoon, 2009), explained that developing countries may be able to become competitive in the global economy only through the adoption of "e-learning, the field of open and distance learning (ODL), and modern learning and teaching concepts to the culture and educational systems of the region" (p. 14).

While some research has examined developing countries' responses to technology implementation and e-learning (Abbad, Morris, \& de Nahlik, 2009; Rumzan et al., 2010), limited research has examined the extent to which teachers integrate technology into teaching. This research examined teachers' perceptions concerning technology use and the integration of technology into teaching. In Jordanian schools, current research on the integration of technology has focused on teachers across disciplines and grade levels. In addition, research suggests Jordanian teachers' use and integration of technology is very low (Al Zaidiyeen, Mei \& Fook, 2010). For these reasons, the current study examined the attitudes of Jordanian seventh to twelfth-grade social studies teachers toward technology, and their perceptions of competencies needed for implementing technology into their classrooms in regards to their age, gender, teaching experience and grade level taught.

\section{Methodology}


The primary purpose of this study was to examine Jordanian seventh to twelfth-grade social studies teachers' perceptions of the competency needed for technology implementation in their classrooms. Specifically, the study examined the differences between teachers' perceptions of the competency needed to implement technology on the basis of their age, gender, teaching experience, and grade-level taught.

\section{Research Design}

This was a quantitative study utilizing a cross-sectional survey design, meaning that the researcher collected data at one point in time with an interest in describing relationships among variables (Tate, 1998). Additionally, this study was largely exploratory in nature. Few researchers have conducted studies on the use of technology by social studies teachers in the Arab world in general, and in Jordan in particular. The goal of this research study was to explore the perceptions of the competency needed to implement technology in their classrooms.

\section{Research Questions}

The specific research questions for the study included the following:

Question One: Is there a statistically significant difference in the perceptions of competency of social studies teachers in basic upper (seventh to tenthgrade) and secondary (eleventh to twelfth-grade) levels toward implementing technology into their classrooms?

Question Two:

(2A) Is there a statistically significant main effect or interaction between age and gender of social studies teachers on their perceptions of the competency needed toward implementing technology into their classrooms?

(2B) Is there a statistically significant interaction between gender and teaching experience of social studies teachers and on their perceptions of the competency needed toward implementing technology into their classrooms?

\section{Sample of Participants and Research Site}

The participants of this research were seventh to twelfth-grade social studies teachers in Amman, Jordan. Permission for the study was obtained from the Ministry of Education, Amman Fifth directorate, and the Colorado State Institutional Review Board (IRB). Following this permission, the researcher requested a list of seventh to twelfth-grade social studies teachers in Amman's Fifth Educational Directorate. The target population for this study consisted of all seventh to twelfthgrade social studies teachers teaching in Amman's Fifth Educational Directorate.

The accessible population has 110 public schools in the Fifth Directorate. Each school has two or three social studies teachers. Thus, the total number of social studies teachers from seventh to 
twelfth grades in this directorate was 221 teachers; 135 males and 86 females. All of the teachers were invited to participate in the study.

\section{Descriptive Summary of Teachers' Characteristics}

The teachers' descriptive information is shown in Table 1 . The total number of participants who completed and returned the Technology Education Survey (TIES) was 221. The response rates for data analysis from each of the school districts were 100 percent. The table shows that 61 percent (135) of the social studies teachers were males and 38 percent (86) were females. Forty-one percent (91) of the participants were in the 31-39-year age range, 32 percent (72) of them were thirty years old or younger, while 26 percent (58) were at least forty years old.

In terms of teaching experience, 29 percent (65) of the participants had eight to thirteen years of experience, 26 percent (59) of the participants had between one and seven years, 22 percent (49) of the participants had between fourteen and eighteen years and nearly 22 percent (48) of the participants had between nineteen and twenty-nine years on the job. More than half of the participants, 57 percent (128), taught at the upper basic level, while 42 percent (93) taught at the secondary level.

Eighty-five percent (189) of the participants stated that they had at least basic access to computers. Among these with access, 69 percent (153) of the participants were using the following software programs which were categorized as basic: Microsoft Word, Power Point, Excel, Microsoft Publisher, PageMaker, Digital Cameras, Internet browsers, Video Cameras. 
Table 1. Social Studies Teachers' Descriptive Statistics

\begin{tabular}{|c|c|c|c|}
\hline Variable & Category & Frequency & Percent \\
\hline \multicolumn{4}{|l|}{ Gender } \\
\hline & Male & 135 & 61.1 \\
\hline & Female & 86 & 38.9 \\
\hline \multicolumn{4}{|l|}{ Age } \\
\hline & 30 and under & 72 & 32.6 \\
\hline & $31-39$ & 91 & 41.2 \\
\hline & 40 and over & 58 & 26.2 \\
\hline \multicolumn{4}{|c|}{ Experience } \\
\hline & $1-7$ & 59 & 26.7 \\
\hline & $8-13$ & 65 & 29.4 \\
\hline & $14-18$ & 49 & 22.2 \\
\hline & $19-29$ & 48 & 21.7 \\
\hline \multicolumn{4}{|c|}{ Level Taught } \\
\hline & Basic Upper Level & 128 & 57.9 \\
\hline & Secondary Level & 93 & 42.1 \\
\hline \multicolumn{4}{|c|}{ Access to Computer } \\
\hline & Yes & 189 & 85.5 \\
\hline & No & 32 & 14.5 \\
\hline \multicolumn{4}{|c|}{ Type of Technology } \\
\hline & Advanced & 36 & 16.3 \\
\hline & Basic & 153 & 69.2 \\
\hline & No Use & 32 & 14.5 \\
\hline
\end{tabular}

\section{Instrumentation}

The instrument for this study was a survey developed by Kelly (2003) called the Technology in Education Survey (TIES). Due to the cultural context of the study, the researcher used an Arabiclanguage version of the survey used by Al Ghazo (2008). Al Ghazo used the TIES to examine technology integration in education of university teachers in Jordan. Permission from Kelly and Al Ghazo was sought and granted for use of the instrument.

The instrument was selected for several reasons. First, the instrument's purpose was highly relevant to the researcher's purpose and had a high reported internal consistency (Kelly, 2003). Second, the TIES had already been translated into the Arabic language. Third, the Arabic version already had established validity and reliability from Al Ghazo's study. Additionally, Wang (2006) successfully used the TIES survey internationally for examining technology integration in Taiwan.

The survey was a structured questionnaire. The survey was divided to three sections: 'Personal and Situational Data', 'Attitudes toward Using Technology', and 'Competency for Using Technology'. The sections were comprehensive and aided in determining social studies teachers' attitudes toward the 
implementing of technology into the classroom and the perceptions that these teachers had regarding the competency needed for implementing technology into the classroom.

The following is a sample of some of the TIES survey questions in the three sextions:

\section{SECTION 1 - Personal Data}

Directions: Please provide the following information for data analysis purposes. All responses are kept strictly confidential (Please do not sign your name).

Today's date:

(1.) Gender: /

(2.) Age

(3.) Number years of teaching experience:

(4.) Grade level taught: Basic Upper Level Secondary Level

(5.) Do you have access to computer technology

No

Yes. If yes, check all that apply. Home School Other (Please Explain)

(6.) Type of technology and software programs you are using. (Check all that apply) Microsoft word PowerPoint Internet browsers Excel Access Microsoft Publisher PageMaker Digital Camera Kid Pix Video Camera Accelerated Reader Cornerstone Language Arts Program Hyper Studio Other (Please list)

\section{SECTION II - Attitude Toward Using Technology}

Directions: Below is a set of statements dealing with using technology in your content area. Rate the IMPORTANCE of each statement by circling the appropriate number for each item. Computerbased Technology (classroom based Instruction technology).

How important or unimportant is it to

1. Use Computer-Based technology as an integral part of classroom instruction?

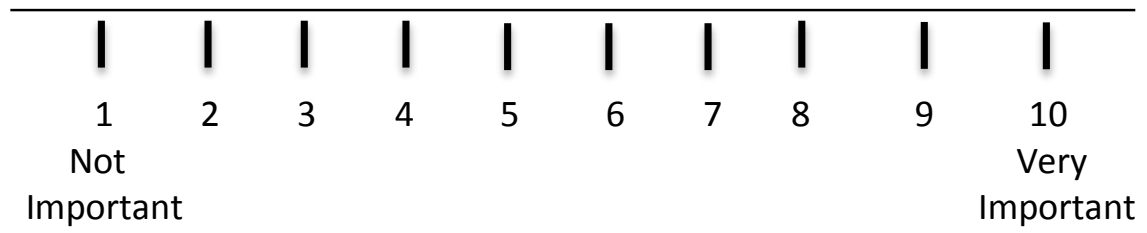


How important or unimportant is it to

2. Motivate students to use Computer-Based technology in a variety of subject-related situations?

\begin{tabular}{|c|c|c|c|c|c|c|c|c|c|}
\hline I & I & 1 & I & 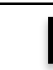 & & | & & & 1 \\
\hline $\begin{array}{c}1 \\
\text { Not } \\
\text { Important }\end{array}$ & 2 & 3 & 4 & & 5 & 6 & & 7 & 8 \\
\hline
\end{tabular}

How important or unimportant is it to

3. Design activities that require students to use electronic sources for gathering specific information?

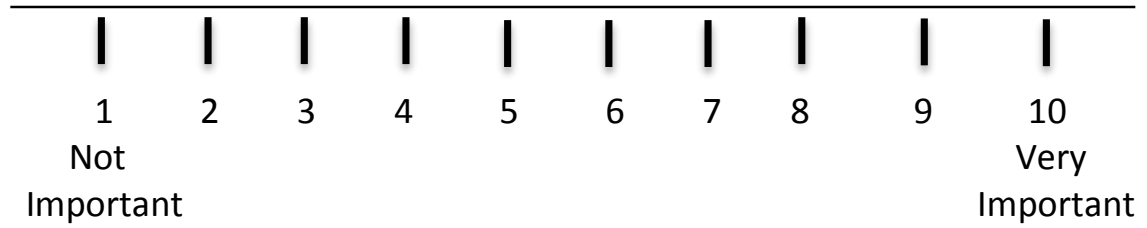

How important or unimportant is it to

4. Structure lessons that help students use Computer-Based technology to enhance desired learning?

\begin{tabular}{cccccccccc}
\hline $\mathbf{|}$ & $\mathbf{|}$ & $\mathbf{|}$ & $\mathbf{|}$ & $\mathbf{|}$ & $\mathbf{|}$ & $\mathbf{|}$ & $\mathbf{|}$ & $\mathbf{|}$ & $\mathbf{|}$ \\
1 & 2 & 3 & 4 & 5 & 6 & 7 & 8 & 9 & 10 \\
$\begin{array}{c}\text { Not } \\
\text { Important }\end{array}$ & & & & & & & & $\begin{array}{c}\text { Very } \\
\text { Important }\end{array}$
\end{tabular}

How important or unimportant is it to

5. Select and design Computer-Based technology related activities that assess each student's knowledge about technology?

\begin{tabular}{cccccccccc}
\hline | & | & | & | & | & | & | & | & | & | \\
1 & 2 & 3 & 4 & 5 & 6 & 7 & 8 & 9 & 10 \\
Not & & & & & & & & & $\begin{array}{c}\text { Very } \\
\text { Important }\end{array}$ \\
Important
\end{tabular}

\section{SECTION 111 - Competency for Using Technology}

Directions: Below is a set of skills dealing with the use of technology in the content areas. Rate YOUR COMPETENCY to perform each skill by circling the appropriate answer for each item: 
Assess your competency to

12. Use Computer-Based technology as an integral part of classroom instruction?

\begin{tabular}{cccccccccc}
\hline I & | & | & | & | & | & | & | & | & | \\
1 & 2 & 3 & 4 & 5 & 6 & 7 & 8 & 9 & 10 \\
Not & & & & & & & & $\begin{array}{c}\text { Very } \\
\text { Competent }\end{array}$ \\
Competent & & & & & & & &
\end{tabular}

Assess your competency

13. To motivate students to use technology in a variety of subject-related situations?

\begin{tabular}{cccccccccc}
\hline I & I & I & | & I & | & I & I & I & | \\
1 & 2 & 3 & 4 & 5 & 6 & 7 & 8 & 9 & 10 \\
$\begin{array}{c}\text { Not } \\
\text { Competent }\end{array}$ & & & & & & & $\begin{array}{c}\text { Very } \\
\text { Competent }\end{array}$
\end{tabular}

Assess your competency to

14. Design activities that require students to use electronic sources for gathering specific information?

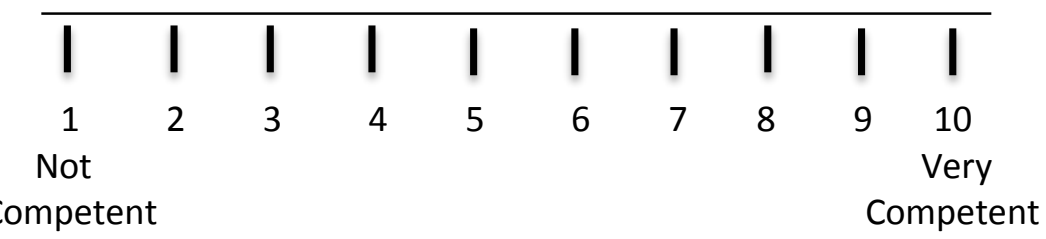

Assess your competency to

15. Structure lessons that help students use Computer-Based technology to enhance desired learning

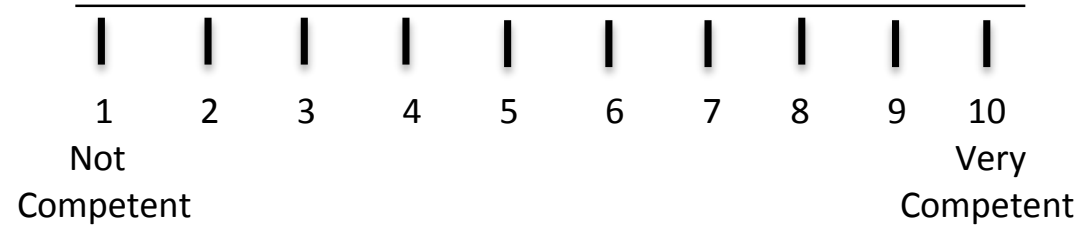

Prior to launching the study, the researcher tested the items of the modified scale to make sure it was suitable and readable for the actual sample. Participants were asked to review the content of the questionnaire and its appropriateness. Participants were encouraged to provide feedback concerning any problems with the survey. Moreover, the researcher also examined the reliability and validity of the instrument before it was implemented. Therefore, the researcher distributed the survey to fifteen participants, with nine males and six females, as a pilot for the actual sample. These participants were working on their master's and doctoral degrees. By doing this, the researcher ran 
Cronbach Coefficient Alpha to examine the internal consistency. Reliability was found to be .77 for the 'Attitudes toward Using Technology' section, and .87 for the 'Competency for Using Technology' section. These scores are both in the acceptable range.

\section{Reliability and Validity of the Instrument}

Kelly's original TIES survey reported a Cronbach Alpha Coefficient of .78 for the 'Attitudes Toward Using Technology' section, and .91 for the 'Competency for Using Technology' section. Kelly established content validity by using a panel of five professors of educational technology employed at Mississippi University (Kelly, 2003). Al Ghazo (2008) established face and content validity for the Arabic version of his instrument with the help of a panel of experts consisting of five university professors who were content experts; three were from the English Language department and two were from the Arabic Language department at Mu'tah University. The expert panel evaluated the instrument, both before and after it was used, and necessary modifications were made. This current study tested internal consistency using Cronbach Coefficient for the 'Attitudes toward Using Technology' section and found a coefficient of .80, and .90 for the 'Competency for Using Technology' section, which indicate a very strong reliability.

\section{Data Analysis}

The study utilized descriptive (e.g. mean and standard deviations) and inferential statistics; $t$-tests, ANOVA, and multiple regression were used to analyze the results. Specifically, the researcher used descriptive statistics such as measures of central tendency and variability, and frequencies to calculate teachers' responses based on demographic data.

\section{Analysis of Complex Associational Questions}

The research questions were answered and used the inferential statistics tests below:

The first research question, "Is there a statistically significant difference in the perceptions of the competency of social studies teachers in basic upper (seventh to tenth-grade) and secondary (eleventh to twelfth-grade) levels toward implementing technology into their classroom?", was answered by calculating a t-test.

Research question 2a, "Is there a statistically significant main effect or interaction between age and gender of social studies teachers and on their perceptions of the competency needed toward implementing technology into their classroom?", was answered by computing factorial design ANOVA.

Research question $2 \mathrm{~b}$, "Is there a statistically significant interaction between gender and teaching experience of social studies teachers and on their perceptions of the competency needed toward implementing technology into their classroom?", was answered by computing factorial design ANOVA. 


\section{Results}

\section{Research Question One}

The first research question explored the issue of competency. Research question one asked: is there a statistically significant difference in the perceptions of the competency needed of social studies teachers in basic upper (seventh to tenth-grade) and secondary (eleventh to twelfth-grade) levels toward implementing technology into their classrooms? A $t$-test was used to examine the second research question. As shown in Table 2, no statistically significant differences were found in the perceptions of the competency needed between basic upper $(M=65.58, S D=20.11)$ and secondary levels $(M=62.16, S D=18.11, t(219)=1.300, p=.195)$. This indicates that social studies teachers do not significantly differ on their perception of competency scores toward implementing technology in social studies classrooms based on the grade level taught. The effect size $d$ is .18 , which is also very small.

Table 2. T-Test for Teachers' Perceptions of Competency Needed Based on Grade Level Taught

\begin{tabular}{lllllll}
\hline Grade Level Taught & $N$ & $M$ & $S D$ & $t$ & $d f$ & $p$ \\
\hline Competency Upper level & 128 & 65.58 & 20.11 & 1.300 & 219 & .195 \\
Secondary level & 93 & 62.16 & 18.11 & & & \\
\hline
\end{tabular}

\section{Research Question 2a}

Research question 2a asked: is there a statistically significant main effect or interaction between age and gender of social studies teachers on their perception of the competency needed for implementing technology into their classroom? Means and standard deviations were computed and then two-way ANOVA tests were computed as well. Table 3 shows that the total mean of perceptions of competency scores of teachers grouped into age categories ranged between 49.50 and 75.72. Female teachers who were thirty or younger and who were thirty-one to thirty-nine scored the highest mean of perception of competency needed for implementing technology in social studies classrooms, higher than all male teachers, whereas male and female teachers who were forty or older scored the same lowest mean of perceptions of competency (49.5). As seen in Table 4 , there is a significant main effect of age on teachers' perceptions of competency $(F(2,215)=38.93$, $p<.05)$. Eta for age was about .52 , which according to Cohen (1988) is a very large effect. There was, however, no significant main effect found for gender on teachers' perceptions of competency $(F(1,215)=2.99, p=.085)$. There was also not a significant interaction between gender and age on teachers' perceptions of competency $(p=.203)$.

Furthermore, the researcher ran a post-hoc test Tukey (fig. 3) to examine where the age differences showed different perceptions of competency. Post hoc indicated mean differences on teachers' perception of competency between 30 and under and both 31-39 $(p<.05)$ and 40 and over $(p<$. $05)$. Likewise, there was also significant mean difference on teachers' perceptions of competency between $31-39$ years old and 40 and over $(p<.05)$. 
Table 3. Means, Standard Deviations, and $\mathrm{n}$ for Teachers' Perceptions of Competency as a Function of Age and Gender

\begin{tabular}{|c|c|c|c|c|c|c|c|c|}
\hline \multirow[b]{2}{*}{ Age } & \multicolumn{3}{|c|}{ Males } & \multicolumn{3}{|c|}{ Females } & \multicolumn{2}{|l|}{ Total } \\
\hline & $n$ & $M$ & $S D$ & $n$ & $M$ & $S D$ & $M$ & SD \\
\hline 30 and under & 38 & 74.50 & 11.80 & 34 & 77.09 & 17.90 & 75.72 & 14.94 \\
\hline $31-39$ & 59 & 60.95 & 16.33 & 32 & 70.50 & 18.62 & 64.31 & 17.67 \\
\hline 40 and over & 38 & 49.53 & 14.46 & 20 & 49.45 & 20.99 & 49.50 & 16.81 \\
\hline Total & 135 & 61.55 & 17.33 & 86 & 68.21 & 21.58 & 64.14 & 19.32 \\
\hline
\end{tabular}

Table 4. Analysis of Variance for Teachers' Perceptions of Competency as a Function of Age and Gender

\begin{tabular}{|c|c|c|c|c|c|}
\hline Variable and source & $d f$ & $M S$ & $F$ & $\eta^{2}$ & $\operatorname{sig}$ \\
\hline \multicolumn{6}{|l|}{ Competency } \\
\hline Age & 2 & 10507.98 & $38.93 *$ & .266 & .000 \\
\hline Gender & 1 & 807.30 & 2.99 & .014 & .085 \\
\hline Age * Gender & 2 & 698.08 & 1.60 & .015 & .203 \\
\hline Error & & & & & \\
\hline
\end{tabular}

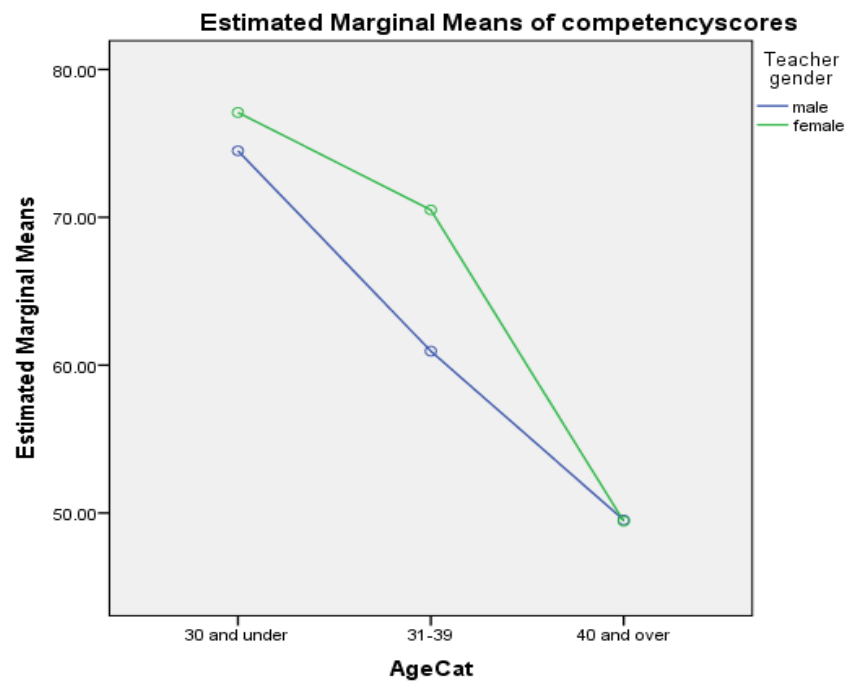

Figure 1: Two-way ANOVA Test Teacher Gender with Age 


\section{Research Question 2b}

Research question $2 \mathrm{~b}$ asked: is there a statistically significant interaction between gender and teaching experience of social studies teachers on their perceptions of the competency needed for implementing technology into their classroom? Means and standard deviations were computed and then two-way ANOVA tests were computed as well. Table 5 shows the total mean of perceptions of competency scores of teachers grouped into teaching experience categories ranged between 49.42 and 76.39. Female teachers with the least teaching experience had higher perceptions of competency for implementing technology in social studies classrooms than male teachers, meanwhile female teachers with the most teaching experience had nearly as high perceptions of competency needed as male teachers. Table 6 shows no significant interaction between gender and teaching experience on teachers' perceptions of competency $(p=.671)$. Furthermore, no significant main effect of gender on teachers' perceptions of competency was found $(F(1,213)=3.05, p=.082)$. There was, however, a significant main effect of teaching experience on teachers' perceptions of competency $(F(3,213)=30.86, p<.05)$. Eta for teaching experience was about .55 , which according to Cohen (1988) is a very large effect.

The researcher ran a post- hoc test Tukey (fig .2) to examine where the teaching experience differences were. Post hoc indicated mean differences on teachers' perceptions of competency between teachers with 1-7 years and with both $14-18$ years of teaching experience $(p<.05)$ and 19-29 teaching experience $(p<.05)$. Likewise, there were significant mean differences on teachers' perceptions of competency between teachers with experience of 8-13 years and with both 14-18 years $(p<.05)$ and $19-29(p<.05)$.

Table5. Means, Standard Deviations, and $\mathrm{n}$ for Teachers' Perceptions of Competency as a Function of Gender and Teaching Experience

\begin{tabular}{|c|c|c|c|c|c|c|c|c|}
\hline \multirow[b]{2}{*}{ Years of } & \multicolumn{3}{|c|}{ Males } & \multicolumn{3}{|c|}{ Females } & \multicolumn{2}{|c|}{ Total } \\
\hline & $n$ & $M$ & $S D$ & $n$ & $M$ & $S D$ & $M$ & SD \\
\hline \multicolumn{9}{|c|}{ Experience } \\
\hline $1-7$ & 35 & 73.97 & 11.87 & 24 & 79.92 & 16.67 & 76.39 & 14.19 \\
\hline $8-13$ & 34 & 66.82 & 14.57 & 31 & 74.35 & 15.46 & 70.41 & 15.36 \\
\hline $14-18$ & 35 & 55.09 & 17.06 & 14 & 56.50 & 22.87 & 55.49 & 18.66 \\
\hline $19-29$ & 31 & 49.03 & 14.00 & 17 & 50.12 & 21.32 & 49.42 & 16.74 \\
\hline Total & 135 & 61.55 & 17.33 & 86 & 68.21 & 21.58 & 64.14 & 19.32 \\
\hline
\end{tabular}


Table 6. Analysis of Variance for Teachers' Perceptions of Competency as a Function of Teaching Experience and Gender

\begin{tabular}{|c|c|c|c|c|c|}
\hline Variable and source & $d f$ & $M S$ & $F$ & $\overline{\eta^{2}}$ & $\operatorname{sig}$ \\
\hline \multicolumn{6}{|l|}{ Competency } \\
\hline Teaching Exp & 3 & 7996.86 & $30.86^{*}$ & .303 & .000 \\
\hline Gender & 1 & 790.24 & 3.05 & .014 & .082 \\
\hline Teaching Experience * Gender & 3 & 133.98 & .517 & .007 & .671 \\
\hline Error $\quad 213$ & & & & & \\
\hline
\end{tabular}



Figure 2: Two-way ANOVA Test Teacher Gender with Teaching Experience

In conclusion, a number of statistically significant results were found in this study. A brief summary of these results follows. A significant interaction was found between age and gender of social studies teachers and their perceptions of competency needed to implement technology. Female teachers who were thirty or younger and who were thirty-one to thirty-nine scored the highest mean of perceptions of competency toward implementing technology in social studies classrooms, higher than all male teachers, while male and female teachers who were forty or older scored the same lowest mean (49.5) of perceptions of competency. Female teachers with the least teaching experience had high perceptions of competency for implementing technology in social studies classrooms, while female teachers with the most teaching experience had lower perceptions of competency than male teachers. 


\section{Discussion}

\section{Sample}

A sample of 221 seventh to twelfth-grade social studies teachers was taken in the Fifth Educational District, Amman, Jordan. The sample consisted of 128 who taught in the basic upper level, and 93 certified as secondary teachers. The study used the Technology in Education Survey (TIES) instrument, which was designed to gather all necessary data needed for testing the two proposed questions. Participants were mailed a hard copy of the surveys. Descriptive and inferential statistics were utilized to report results for each of the research questions.

\section{Research Question One}

Is there a statistically significant difference in the perceptions of the competency needed of social studies teachers in basic upper (seventh to tenth-grade) and secondary (eleventh to twelfth-grade) levels toward technology?

Results showed no differences in teachers' perceptions of the competency needed with technology between basic upper and secondary social studies teachers. Teachers' perceptions of competency needed were similar regardless of the grade level they taught. This finding matches Woods, Karp, Miao, \& Perlman's (2008) study that also indicated no significant differences were found in terms of school grade levels.

This study's results support Kassaimih (2006) findings. Kassaimih results showed that there were no significant differences in teachers' perceptions among the four grade levels. Kassimih concluded that Jordan has not yet found success in integrating technology that may allow teachers to have different perceptions and experiences with it.

The lack of technology resources and a lack of time are possible reasons that hinder teachers from implementing technology in different settings in these schools. Another possible reason is that grade-level taught is probably not specifically associated with levels of technology in the curricula.

\section{Research Question 2A}

Is there a statistically significant (main effect) or interaction between age and gender of social studies teachers and their perceptions concerning competency needed toward implementing technology into their classroom? Results showed that female teachers who were thirty or younger, or were thirty-one to thirty-nine, scored the highest mean of perceptions of competency needed toward implementing technology in social studies classrooms, higher than all male teachers. However, male and female teachers who were forty or older scored the same lowest mean of perceptions of competency. This result corroborates King's (1999) finding of significant differences between male and female teachers' technology competency. However, King (1999) found that male teachers tended to perceive themselves to be more competent than female teachers, which contradicts the current finding that indicated female teachers had higher perceptions of 
competency than male teachers. These current findings may be due to the fact that these specific female teachers had more hours of training than the male teachers, and spent more time on average with computers than the male teachers in the study.

This study also found a significant main effect of age on teachers' perceptions of competency, indicated by the youngest female teachers having higher perceptions of competency scores than the youngest male teachers. Whereas, male and female teachers who were forty or older scored the same lowest mean of perceptions of competency (49.5). Two possible explanations for this finding could be the fact that the youngest teachers are part of the new generation born with access to computers and technology, and perhaps, they see themselves as more competent because they gained more experience with technology, while the oldest teachers had less chance of gaining experience with technology. This is consistent with King's (1999) study, which indicated significant differences were found between the youngest teachers (20-30 year-olds) and the oldest (41-50year-olds).

This study's findings are consistent with a study conducted by Czaja and Shark (1998) which investigated age differences in attitudes toward computers. Their findings revealed that older people have more negative attitudes toward computer technology than younger people. Also, their study investigated age differences in attitudes toward computers as a function of experience with computers and computer task characteristics. Their results found differences based on age in overall attitudes; age effects were found for the dimensions of comfort, efficacy, dehumanization, and control. However, their results showed that those experienced with computers had positive attitudes, regardless of age.

Also, this study result informed Breisser (2006) which indicated that female teachers had better perceptions of technology competence than male teachers. This may indicate the teachers' awareness of the availability of technology tools and the benefits of them to their teaching.

Similarly, Adodo's (2012) study showed a significant difference between the male and female preservice teachers towards computer skills. The relationship between interest/attitude and competency was low, positive, but significant, as well as the relationship between gender and competency was significant.

\section{Question 2B.}

Is there a statistically significant interaction between gender and teaching experience of social studies teachers and their perceptions of the competency needed toward implementing technology into their classroom?

Results showed that female teachers with the least teaching experience had higher perceptions of competency for implementing technology in social studies classrooms than male teachers, while female teachers with the most teaching experience had lower perceptions of competency scores than male teachers. Thus, a significant main effect of teaching experience on teachers' perceptions of competency was found. 
One possible explanation for this finding is due to the fact that the teachers' age, skills, and knowledge of technology enable them to properly implement technology in the classroom. This means that the youngest teachers who have the least teaching experience are more competent than the oldest teachers with more teaching experience. This finding is inconsistent with Woods, Karp, Miao \& Perlman's (2008) study that indicated male teachers had higher perceptions of competency than female teachers, while no significant difference in teaching experience and grade level taught were found in a general teaching setting. On the other hand, Woods, Karp, Miao \& Perlman (2008) also examined teachers' perceptions of competency towards technology in a specific teaching setting (i.e. Physical Education). It was shown that significant differences were found based on grade-level taught, but no significant differences were found based on gender and teaching experience. The results of the current study are coraborated by Sa'ari, Luan, and Roslan (2005) study which examined teachers' attitudes and perceived competency towards information technology. Their results showed that most teachers who had teaching experience ranging between nine to forteen years had positive attitudes towards information technology.

Finally, this current study identified predictors of teachers' perceptions of competency to implement technology based on the variables of gender, grade-level taught and teaching experience. These variables are clear in the literature with some other factors that might impact the perception toward integrating technology.

\section{Limitations of the Study}

Several limitations existed in this study. First, the study sample was found by convenience and limited to seventh to twelfth-grade social studies teachers employed in public schools in the Fifth Educational Directorate in Amman, Jordan. The sample was not randomly selected, which limits the external validity of the study; therefore, the results of the study can't be generalized to the larger group of teachers in Jordan. Second, the study used a cross-sectional survey design; consequently it is limited to this specific period of time.

Finally, the survey information depended on self-reported data and the responses of participants provided were based entirely on the attitudes of the teachers and on their perceptions of their competencies; therefore, the results might be affected by the teachers' social desirability to provide desired information rather than accurate information.

\section{Recommendations for Future Research}

After the completion of this study, a number of recommendations for future research can be made. These include the following. First, this study could be replicated using the same methodology but in different directorates in Jordan that also have a large number of teachers. This would make the results more generalizable. Another further research project could investigate the perceptions and attitudes of school principals and counselors.

This study was quantitative, but further research could be qualitative by conducting interviews and observations to gain in-depth information that could enrich the findings of this study and create a 
better understanding of technology usage in Jordan. This study used a cross-sectional design and a short period of time to collect the data. It would be helpful for further research to be a longitudinal study design to obtain more description of the subject and discover the issues of technology.

This study examined factors such as, age, gender, teaching experience and grade-level taught. It is recommended to examine other factors that may affect teachers from integrating technology, such as: school support, technical support, teachers' academic degree, and training programs.

\section{Conclusion}

This study has contributed to the growing body of knowledge in the field of technology integration and social studies teachers, particularly in Arab countries. To this end, the study investigated social studies teachers' perceptions of competency needed for implementing technology in Jordanian schools.

This study found that the youngest female teachers had the highest mean of perceptions of competency needed for implementing technology in social studies classrooms, even higher than the youngest male teachers. This study also showed that female teachers with the least teaching experience had higher perceptions of competency for implementing technology in social studies classrooms than male teachers, while female teachers with the most teaching experience had lower perceptions of competency scores than male teachers.

Finally, this current study identified predictors of teachers' perceptions of competency to implement technology based on the variables of gender, grade-level taught and teaching experience. These variables are clear in the literature with some other factors that might impact the perception toward integrating technology.

This study is a preliminary step in this area and the researcher plans to conduct further investigations into the factors that might affect technology integration in Jordan and other developing countries. The researcher also hopes that this study will help principals, administrators, teachers, and parents to understand teachers' attitudes and perceptions concerning the competency needed to implement technology. This, in turn, will lead to professional development and the improvement of technology resources for teachers.

\section{References}

Abbad, M., Morris, D., \& de Nahlik, C. (2009). Looking under the bonnet: Factors affecting student adoption of e-learning systems in Jordan. International Review of Research in Open and Distance Learning, 10(2), 1-25.

Abuhmaid, A. (2008). An analysis of ICT integration within the Jordanian education system (Unpublished doctoral dissertation). The University of Technology, Sydney. 
Abu Samak, Z. (2006). An exploration of Jordanian English language teachers' attitudes, skills, and access as indicator of information and communication technology integration in Jordan (Unpublished doctoral dissertation). The Florida State University, USA.

Adodo, S., O. (2012). A predictive study of pre-service teachers' gender, self-concept, Interest and attitude towards interactive computer technology (ICTS) in Nigeria universities faculties of Education. Journal of Educational and Social Research, 2(3) 145-150.

Akengin, H. (2008). Opinions of prospective social studies teachers on the use of information technologies in teaching geographical subjects. Journal of Instructional Psychology, 35(2), 126-139.

Alazzi, K. (2008). The influence of historical and political events on the development of social studies education in Jordan's secondary schools. American Education History Journal, 35(2), 331-345.

Alazzi, K. (2008). Why is social studies education in Jordan a prisoner to the past? : A study of cross-history and cultural perspectives. Essays in Education, 23, 1-16.

Al Ghazo, A. (2008). Technology integration in university teachers' education programs in Jordan: Comparisons of competencies, attitudes and perceptions toward integrating technology in the classroom (Unpublished doctoral dissertation). University of Illinois, USA.

Allison, P.D. (1999). Multiple regression: A primer. Thousand Oaks, CA: Pine Forge Press.

Al Mekhlafi, A. \& Al Meqdadi, F. (2010). Teachers' perceptions of technology integration in the United Arab Emirates School Classrooms. Journal of Educational Technology \& Society, 13(1), 165-175.

Al Zaidiyeen, N., Mei, L., \& Fook, F. (2010). Teachers' attitudes and levels of technology use in classrooms: The case of Jordan schools. International Education Studies, 3(2), 211-218.

Bakr, S. (2011). Attitudes of Egyptian teachers towards computers. Contemporary Educational Technology, 2(4), 308-318.

Breisser, S. R. (2006). An examination of gender differences in elementary constructionist classrooms using Lego/Logo instruction. Computers in the Schools, 22, 7-19.

Cohen, J. (1988). Statistical power analysis for the behavioral sciences. Routledge Academic.

Czaja, J, S. \& Shark, J. (1998). Age differences in attitudes toward computers. Journal of Cemnlology: Psychological Science, 53(5), 329-340.

Dirani, K. M. \& Yoon, S. W. (2009). Exploring open distance learning at a Jordanian university: A case study. The International Review of Research in Open and Distance Learning, 10(2), 1-18.

Erdogan, T. (2011). Turkish primary school teachers' perceptions of school culture regarding ICT integration. Educational Technology Research \& Development, 59(3), 429-443.

El-Hmaisat, H. (1998). The skills level of Jordanian teachers' basic education in the area of instructional media. International Journal of Instructional Media, 25(3), 313-327.

Goedde, A. M. (2006). Factors predicting preservice teacher technology competency. Bowling Green State University). ProQuest Dissertations and Theses. Retrieved on 18 June 2014 from http://search.proquest.com/docview/305341344?accountid=10223. (305341344). 
Gorder, L. (2008). A study of teacher perceptions of instructional technology integration in the classroom. Delta Pi Epsilon Journal, 50(2), 63-76.

Gorder, L. M. (2009). Is technology integration finding its way into the classroom? Journal for Computing Teachers, 1(9), 63-76.

Hew, K. \& Brush, T. (2007). Integrating technology into K-12 teaching and learning: Current knowledge gaps and recommendations for future research. Educational Technology Research \& Development, 55(3), 223-252.

Kassaimih, A. (2006). Technology literacy: A phenomenological view of the teachers' perceptions of technology integration in Jordan (Unpublished doctoral dissertation). Oklahoma State University, USA.

Kelly, B. T. (2003). Comparisons of Mississippi elementary and secondary teachers' attitudes and perceptions of competency for integrating technology in the classroom (Unpublished doctoral dissertation). Mississippi State University, USA.

Khaswneh, O. \& Al-Awidi, H. (2008). The effect of home computer use on Jordanian children: A parent perspective. Journal of Educational Computing Research, 39(3), 267-284.

King, B. N. G. (1999). The current state of technology competencies of teachers in Newfoundland and Labrador schools. Memorial University of Newfoundland (Canada). ProQuest Dissertations and Theses. Retrieved on 18 June 2014 from http://search.proquest.com/ docview/304542203? accountid=10223. (304542203).

$\mathrm{Li}, \mathrm{Q}$. (2007). Student and teacher views about technology: A tale of two cities? Journal of Research on Technology in Education, 39(4), 377-397.

Lu, R. \& Overbaugh, R. (2009). School environment and technology implementation in k-12 classrooms. Computers in the Schools, 26(2), 89-106.

Rumzan, I., Chowdhury, I., Mirza, S., \& Idil, R. (2010). An integrated learning management system for Islamic Studies: An innovation from Jordan. Educational Technology, 50(3), 29-32.

Sa'ari, J. R., Luan, W. S., \& Roslan, S. (2005). Attitudes and Perceived Information Technology Competency among Teachers. Malaysian Online Journal of Instructional Technology, 2(3), 70-77.

Spaulding, M. W. (2007). Comparison of preservice and in-service teachers' attitudes and perceived abilities toward integrating technology into the classroom. The University of Memphis. ProQuest Dissertations and Theses. Retrieved on 18 June 2014 from http://search.proquest. com/docview/304717245?accountid=10223. (304717245).

Tate, R. (1998). An introduction to modeling outcomes in the behavioral and social sciences (2nd edition). Minnesota: Burgess International Group.

Ching, S., Hung, D., \& Lee, C. (2008). Beliefs about teaching and uses of technology among preservice teachers. Asia-Pacific Journal of Teacher Education, 36(2), 163-174.

Vannatta, R. \& Fordham, N. (2004). Teacher dispositions as predictors of classroom technology use. Journal of Research on Technology in Education, 36(3), 253-271. 
Wang, J. (2006). Technology integration in university teacher education programs in Taiwan. Dissertation Abstract International, 67(10), doi :(UMI No. 3240053).

Woods, M. L., Karp G. G., Miao, H., \& Perlman, D. (2008). Physical educators' technology competencies and usage. Physical Educator: A Magazine for the Profession, 65(2), 82-99.

Correspondence: Mohammad Al Bataineh, Assistant Professor, Jordan University of Science and Technology, Irbid City, Jordan 